\title{
Original Article \\ Determination of emission of iron oxides from the welding process on the basis of mathematical models
}

\author{
Karolina Weronika Pikulik 1 (D), Jarosław Robert Mikołajczyk 2* (D) \\ 1 Laboratorium “BIOCHEMIK” Sp. z o.o., Śmiłowo, Poland; karolina.pila1@wp.pl (K.P.) \\ 2 Stanisław Staszic University of Applied Sciences in Piła, Poland \\ * Correspondence: jmikolajczyk@puss.pila.pl (J.M.)
}

Received: 01.10.2020; Accepted: 12.02.2021

\begin{abstract}
Oxygen in metals is most often present in the form of oxides, including: $\mathrm{FeO}, \mathrm{Fe}_{2} \mathrm{O}_{3}, \mathrm{Fe}_{3} \mathrm{O}_{4}$. The complexity of the welding process means that oxygen compounds can enter both the liquid metal and the atmosphere, causing negative effects. A welder is exposed to harmful emission of oxides entering the human body through the respiratory system or pores in the skin. The essence of the problem is so serious that standards for air purity and determination of amount of oxides at workplaces have been introduced. The article presents the results of research on the influence of the welding current intensity on the emission of air pollutants (in particular the emission of iron oxides) of the inhalable and respirable fractions. The bench tests were carried out on the basis of the applicable standards for air quality at welding stations. Based on the test results, on the basis of the $\mathrm{R}$ program, mathematical models of the emission of iron oxides generated during the welding process were developed. It was observed that with the increase of the welding current, the average value of the emission of iron oxides - both the inhalable and respirable fractions - increases. For both fractions, it was also noted that the model values are closer to the values measured in the model No. 1.
\end{abstract}

Keywords: welding smoke; respirable fraction; inhalable fraction; iron oxide

\section{Introduction}

The subject of the research was the process of air pollutant emission occurring during welding, visible in the form of welding smoke. This smoke contains various pollutants that depend on many factors, including on the type of joined elements, welding method, type of welding equipment used. Depending on the particle size, welding smoke can be divided into:

- inhalable fraction (inhaled through the nose and mouth),

- respirable fraction with particle sizes smaller than $0.001[\mathrm{~mm}]$.

The presence of oxygen in steel is harmful as it affects the type, content, form and decomposition of the oxides. In addition, it oxidizes (burns out) valuable alloying elements during the welding process, thus depleting the weld material. The presence of oxygen in steel increases its sensitivity to aging, delamination and brittleness cracking, and hot brittleness. In metals, oxygen is most often present in the form of oxides, including: $\mathrm{FeO}$ (dissolved in liquid steel up to $0.2 \%$ ), $\mathrm{Fe}_{2} \mathrm{O}_{3}, \mathrm{Fe}_{3} \mathrm{O}_{4}$. The emission of oxides formed during welding goes both towards the weld, towards the slag (if it is formed) and towards the atmosphere. Thus, it poses a health risk to the welder, who gets these oxides into the body, whether through the respiratory system or the skin.

In order to protect the health of welding workers against all types of welding smokes, the legislator in Poland has defined the concentrations of hazardous substances that may be present in the air. These standards become the basis for the subsequent assessment of the exposure of the welding worker. They are included in the Regulation of the Minister of Family, Labor and Social Policy of June 12, 2018 on the maximum allowable concentrations and intensities of factors harmful to health in the work environment.

This paper presents the development of mathematical models of the emission of iron oxides formed during the welding process, based on the results of bench tests.

\section{Materials and methodology of the research}

In order to characterize the course of the pollutant emission process, bench tests were carried out. Tests of welding fillet welds using the MAG method (Metal Active Gas) of elements made of S235JR steel 
with a thickness of $4 \mathrm{~mm}$ were made, with the use of 3 welding current values: $110 \mathrm{~A}, 130 \mathrm{~A}$ and $150 \mathrm{~A}$. The chemical composition of the steel is given in table I.

Table I. Chemical composition of steel S235JR (\% by weight) [10]

\begin{tabular}{ccccccc}
\hline $\mathbf{C}$ & $\mathbf{M n}$ & $\mathbf{P}$ & $\mathbf{S}$ & $\mathbf{F e}$ & $\mathbf{N}$ & $\mathbf{C u}$ \\
\hline 0.17 & 1.40 & 0.04 & 0.04 & reszta & 0.012 & 0.55 \\
\hline
\end{tabular}

The following factors were adopted as constant factors in this study:

- type of material to be welded - structural non-alloy steel S235JR;

- shielding gas mixture - symbol M21 with $\mathrm{Ar}+18 \% \mathrm{CO}_{2}$ content according to PN-EN ISO 14175;

- sheet thickness $-4 \mathrm{~mm}$;

- type of weld - fillet;

- type of ventilation used - natural (gravity);

- electrode wire diameter - $\varnothing 1.2[\mathrm{~mm}]$;

- used copper welding wire, classification EN400-G4Si1;

- electrode wire feed $-2.0[\mathrm{~m} / \mathrm{min}]$;

- arc voltage;

- welding device - semi-automatic welding machine by LINCOLN POWERTEC 305C;

- welding method - MAG type;

- sampling time.

The random, uncontrolled input factors - disturbances include, among others:

- contamination of welded surfaces;

- fluctuations in the flow of the shielding gas mixture;

- welding current drops;

- noise;

- optical radiation.

The air pollutant emission test during the welding process was carried out according to PN-Z-040087:2002 + Az 1:2004, Air purity protection - Air sampling - Principles of air sampling in work places and interpretation of results.

The measure of air pollution is amount of compounds deposited on the filters. The filters collected during the welder's work were subjected to physicochemical analysis. As a personal aspirator, the GILIAN GilAir3 device with a built-in flow stabilizer, pulsation damping system and flow disturbance indicator was used. Each time, before sampling, the aspirator was adjusted, and after sampling, the air flow in the aspirator was checked in the in-house laboratory.

In order to assess air pollution during the welding process, the following chemicals were tested:

- Iron oxides calculated as Fe - iron (III) oxide, iron (II) oxide, iron (II) iron (III) oxide - inhalable fraction;

- Iron oxides calculated as $\mathrm{Fe}$ - iron (III) oxide, iron (II) oxide, iron (II) iron (III) oxide - respirable fraction.

The abovementioned chemicals were identified based on PN-Z-04469:2015-10, Air purity protection Determination of iron oxides in respirable fraction of aerosol in workplaces by flame atomic absorption spectrometry.

\section{Results of the research}

First, the emissions of iron oxides calculated as Fe - iron (III) oxide, iron (II) oxide, iron (II) iron (III) oxide - inhalable fraction were assessed. The data obtained are presented in table II. Then, in order to analyze the results, the data was implemented in the $\mathrm{R}$ program. A box plot was generated using the $\mathrm{R}$ program (Fig. 1) and the values of selected statistical parameters (Table III) were determined, i.e.:

- Min - minimum value;

- 1stQu. - lower (first) sample quartile $\left(\mathrm{Q}_{1}\right)$;

- Median - median ('middle value' $\mathrm{Q}_{2}$ );

- Mean - arithmetic mean;

- 3rdQu. - upper (third) sample quartile $\left(\mathrm{Q}_{3}\right)$;

- Max - maximum value;

- IQR - interquartile range;

- $\mathrm{R}$ - sample range;

- $\mathrm{s}$ - standard deviation;

- $\mathrm{d}_{1}$ - standard deviation from the mean value. 
Table II. Iron oxides - inhalable fraction $\left[\mathrm{mg} / \mathrm{m}^{3}\right]$

\begin{tabular}{cccc}
\hline No. & $\mathbf{I = 1 1 0}[\mathbf{A}] ;$ & $\mathbf{I = 1 3 0}[\mathbf{A}] ;$ & $\mathbf{I = 1 5 0}[\mathbf{A}] ;$ \\
\hline 1. & 1.17 & 1.27 & 1.54 \\
2. & 1.19 & 1.24 & 1.50 \\
3. & 1.15 & 1.29 & 1.49 \\
4. & 1.18 & 1.23 & 1.51 \\
5. & 1.16 & 1.30 & 1.54 \\
6. & 1.21 & 1.25 & 1.58 \\
7. & 1.20 & 1.29 & 1.55 \\
8. & 1.19 & 1.28 & 1.49 \\
9. & 1.18 & 1.24 & 1.54 \\
10. & 1.16 & 1.25 & 1.45 \\
\hline
\end{tabular}

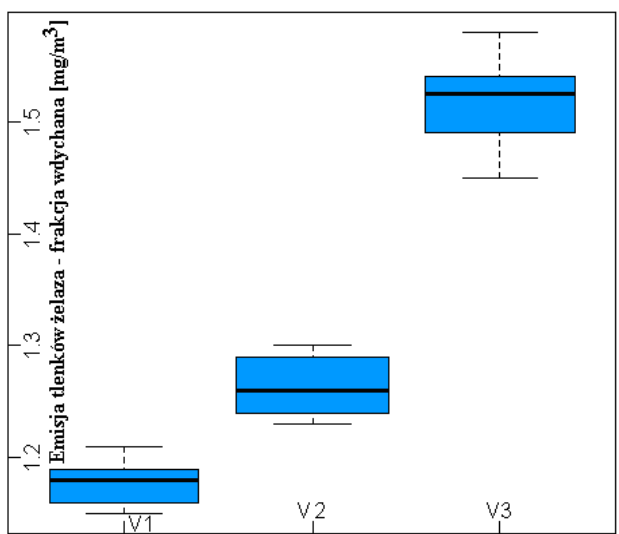

Fig. 1. A box plot generated in $\mathrm{R}$ software pertaining to the emission of iron oxides - inhalable fraction during the welding process for the welding current: V1 - I=110 A; V2 - I=130 A; V3 - I=150 A

Table III. A set of selected statistical parameters for measured iron oxides emissions of inhalable fraction during the welding process

\begin{tabular}{ccccccccccc}
\hline $\begin{array}{c}\text { Current } \\
\text { I[A] }\end{array}$ & Min & 1stQu. & Median & 3rdQu. & Max & IQr & R & s & d1 & Mean \\
\hline 110 & 1.15 & 1.163 & 1.180 & 1.190 & 1.21 & 0.0275 & 0.06 & 0.019 & 0.015 & 1.179 \\
130 & 1.23 & 1.242 & 1.260 & 1.288 & 1.30 & 0.0450 & 0.07 & 0.025 & 0.022 & 1.264 \\
150 & 1.45 & 1.492 & 1.525 & 1.540 & 1.58 & 0.0475 & 0.13 & 0.037 & 0.031 & 1.519 \\
\hline
\end{tabular}

In the next stage, in order to generate mathematical models, the calculated average values of the emission of iron oxides - inhalable fraction were implemented into the $\mathrm{R}$ program and two polynomial models were built:

- $\quad$ model No. 1 (inhalable iron oxide - welding current) - first-order simple regression (Fig. 2);

- model No. 2 (inhalable iron oxide - welding current) - second degree curvilinear regression (Fig. 3).

After determining the values of the coefficients of the models, their diagnostics was performed in order to check their compliance with the measured results (Table IV). Then, from the set of models, one was selected that best suited the measured values of the emission of iron oxides - inhalable fraction (Fig. 4).

Table IV. Comparison of the calculated mean value of the emission of iron oxides - the inhalable fraction during the welding process with model values

\begin{tabular}{cccc}
\hline Current I[A] & Model No. 1 $\left[\mathrm{mg} / \mathrm{m}^{3}\right]$ & Model No. 2 $\left[\mathrm{mg} / \mathrm{m}^{3}\right]$ & Mean $\left[\mathrm{mg} / \mathrm{m}^{3}\right]$ \\
\hline 110 & 1.151 & 867.505 & 1.179 \\
130 & 1.321 & 1205.433 & 1.264 \\
150 & 1.491 & 1598.881 & 1.519 \\
\hline
\end{tabular}


Model No. 1 (simple regression) for iron oxides - inhalable fraction is determined by the equation:

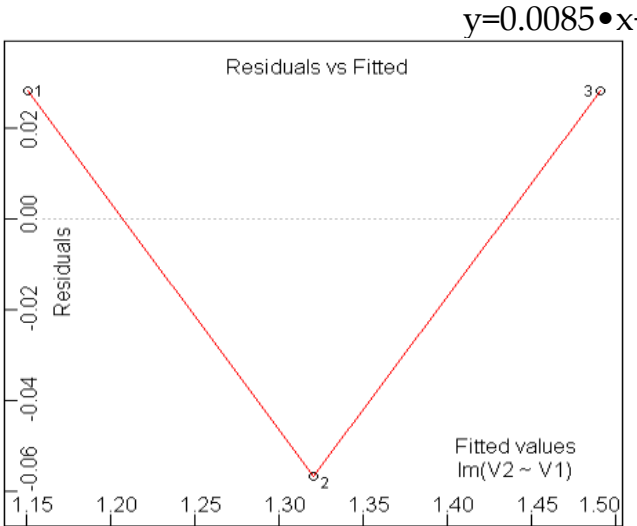

(a)

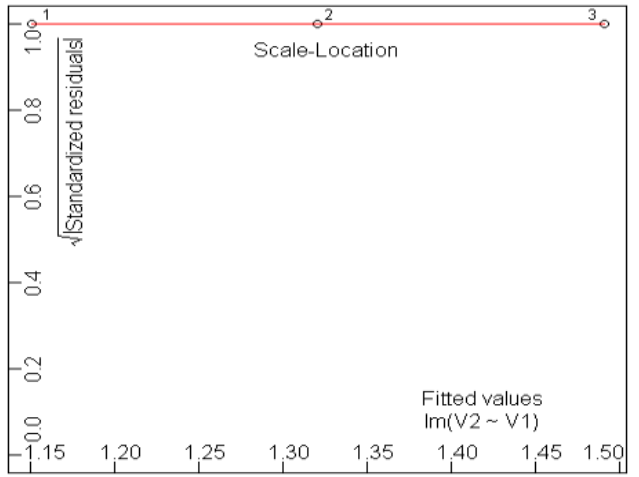

(c)

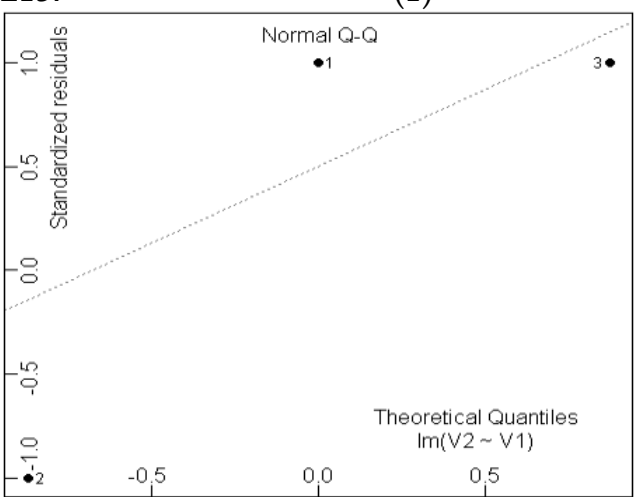

(b)

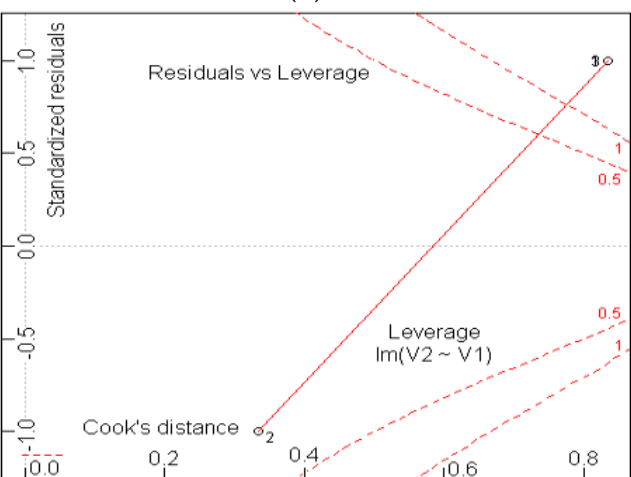

(d)

Fig. 2. Diagnostic charts for model No. 1 (iron oxides - inhalable fraction -- welding current, simple regression)

Model No. 2 (second degree curvilinear regression) is determined by the equation:

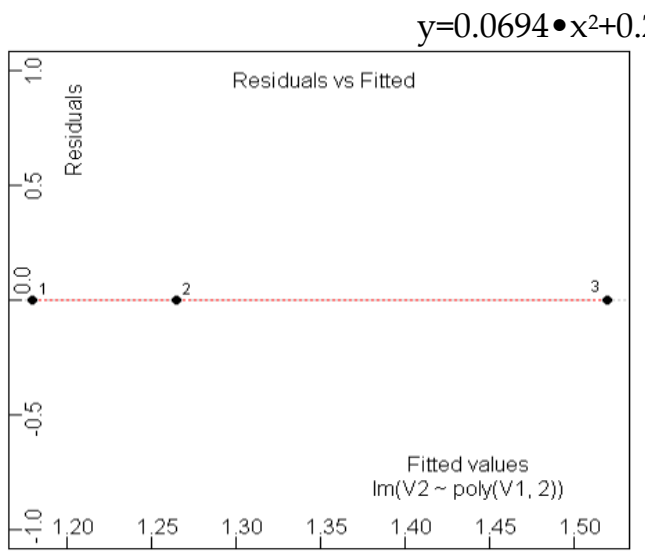

(a)

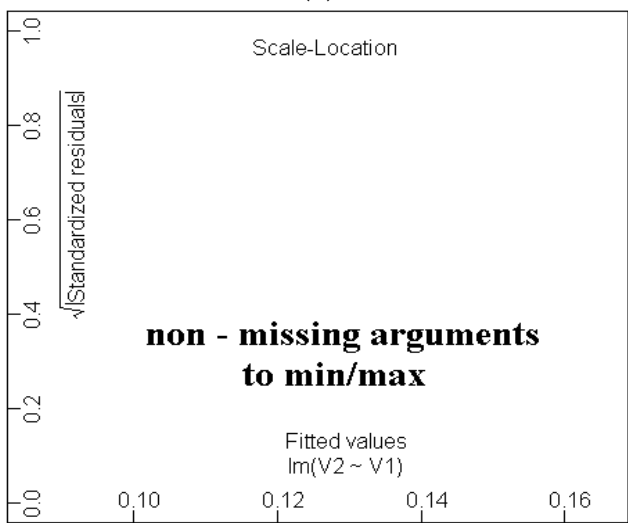

(c)
(2)

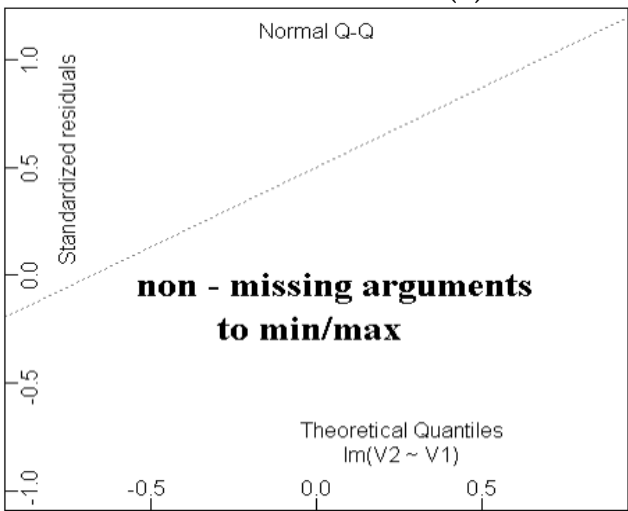

(b)

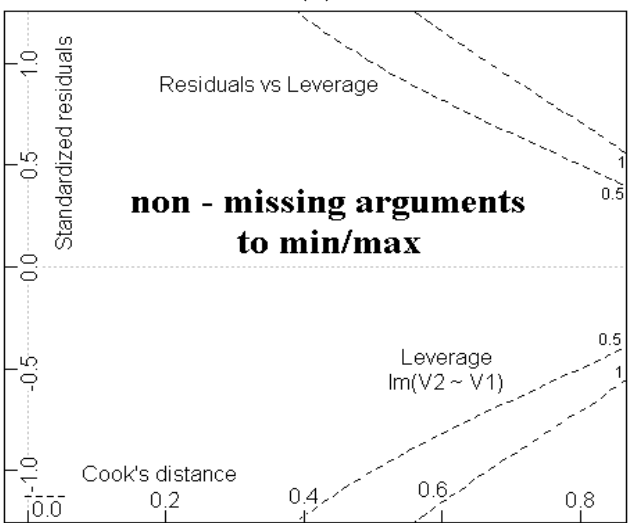

(d)

Fig. 3. Diagnostic charts for model No. 2 (iron oxides - inhalable fraction - welding current, second degree curvilinear regression) 


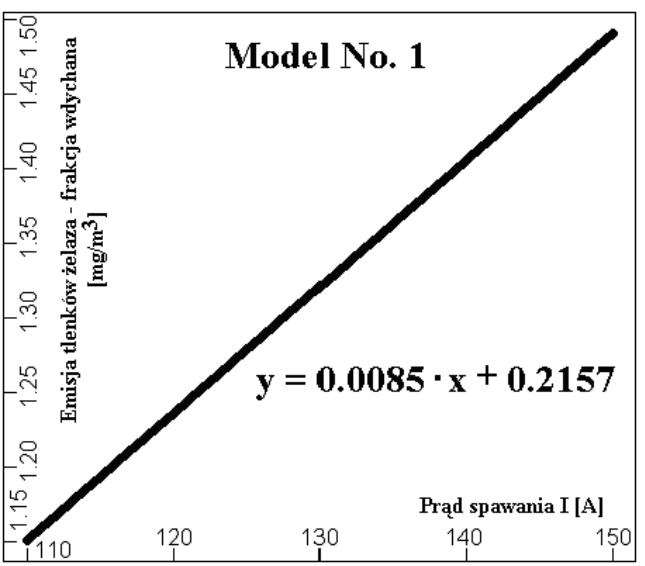

(a)

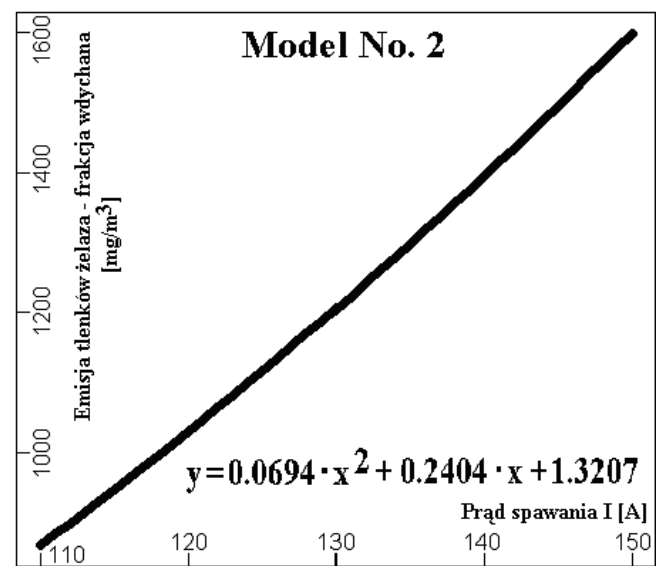

(b)

Fig. 4. Graph of the dependence of the emission of iron oxides - inhalable fraction on the welding current based on: a) model No. 1, b) model No. 2

The data on the emission of iron oxides - respirable fraction was similar. Data for the emission of iron oxides - respirable fraction collected during the tests are presented in table $\mathrm{V}$, box plot in figure 5, values of selected statistical parameters in table VI. On the other hand, the polynomial models are presented in figures 6 and 7, and the comparison of the average emission of iron oxides - respirable fraction during the welding process with the model values is presented in table VII.

Table V. Iron oxides calculated as Fe-iron (III) oxide, iron (II) oxide, iron (II) iron (III) oxide - respirable fraction [mg/m³]

\begin{tabular}{cccc} 
No. & $\mathbf{I = 1 1 0}[\mathbf{A}] ;$ & $\mathbf{I}=\mathbf{1 3 0}[\mathbf{A}] ;$ & $\mathbf{I = 1 5 0 [ A ] ;}$ \\
\hline 1. & 0.93 & 1.07 & 1.38 \\
2. & 0.91 & 1.05 & 1.34 \\
3. & 0.90 & 1.11 & 1.35 \\
4. & 0.94 & 1.09 & 1.39 \\
5. & 0.95 & 1.13 & 1.37 \\
6. & 0.96 & 1.06 & 1.43 \\
7. & 0.94 & 1.10 & 1.40 \\
8. & 0.95 & 1.09 & 1.34 \\
9. & 0.95 & 1.06 & 1.42 \\
10. & 0.94 & 1.09 & 1.36 \\
\hline
\end{tabular}

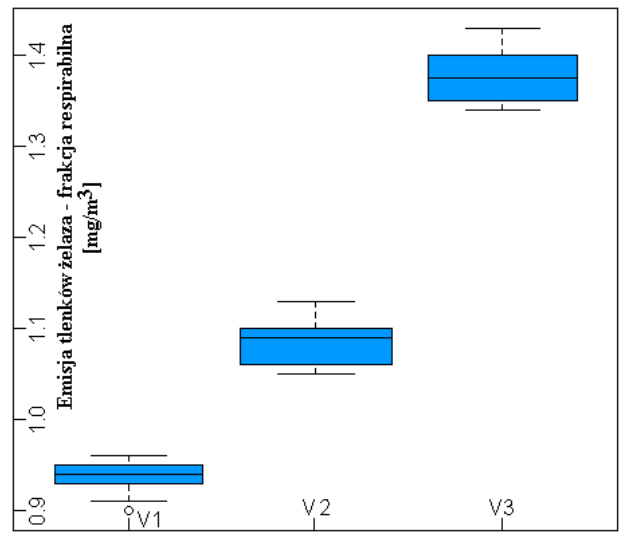

Fig. 5. A box plot generated in $\mathrm{R}$ software pertaining to the emission of iron oxides - respirable fraction during the welding process for the welding current: V1 - I=110 A; V2 - I=130 A; V3 - I=150 A

Table VI. A set of selected statistical parameters for measured iron oxides emissions of respirable fraction during the welding process

\begin{tabular}{ccccccccccc}
\hline Current I[A] & Min & 1stQu. & Median & 3rdQu. & Max & IQr & R & s & d1 & Mean \\
\hline 110 & 0.90 & 0.932 & 0.940 & 0.950 & 0.96 & 0.017 & 0.06 & 0.018 & 0.014 & 0.937 \\
130 & 1.05 & 1.062 & 1.090 & 1.097 & 1.13 & 0.035 & 0.08 & 0.025 & 0.020 & 1.085 \\
150 & 1.34 & 1.353 & 1.375 & 1.397 & 1.43 & 0.045 & 0.09 & 0.031 & 0.026 & 1.378 \\
\hline
\end{tabular}


Model No. 1 (simple regression) for iron oxides - respirable fraction is determined by the equation:

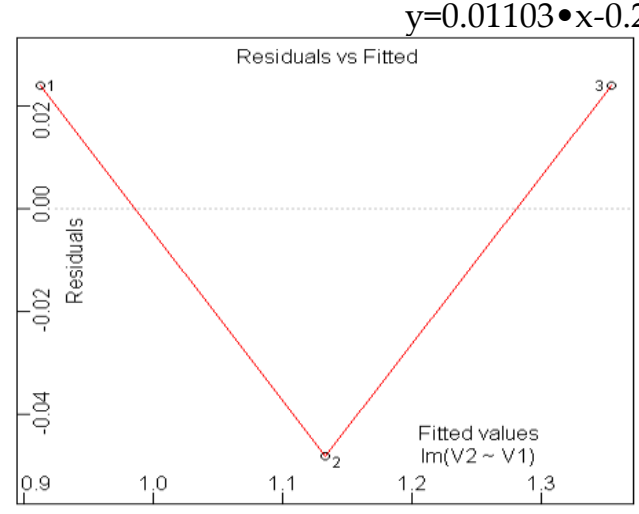

(a)

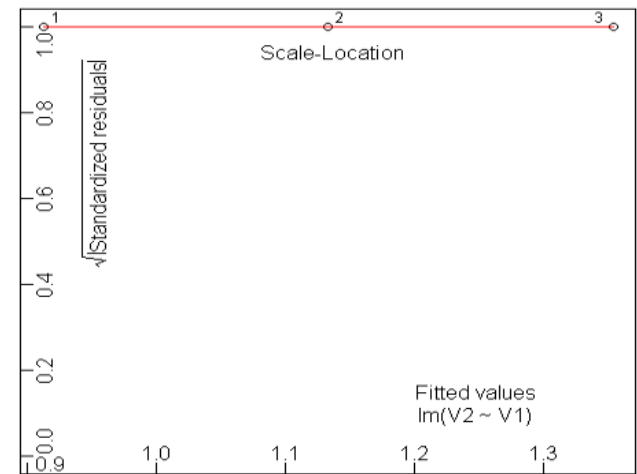

(c)

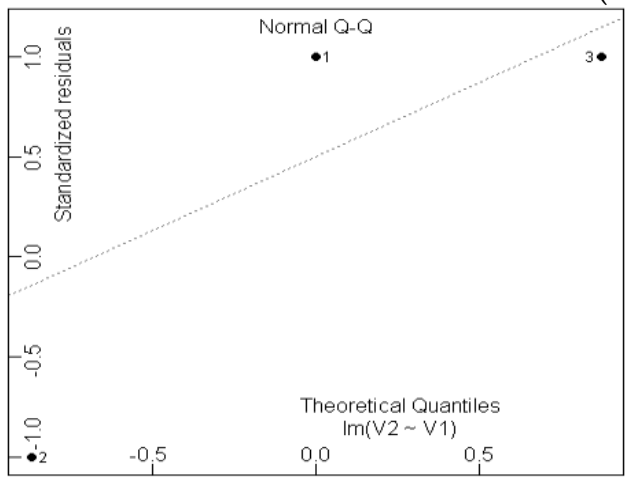

(b)

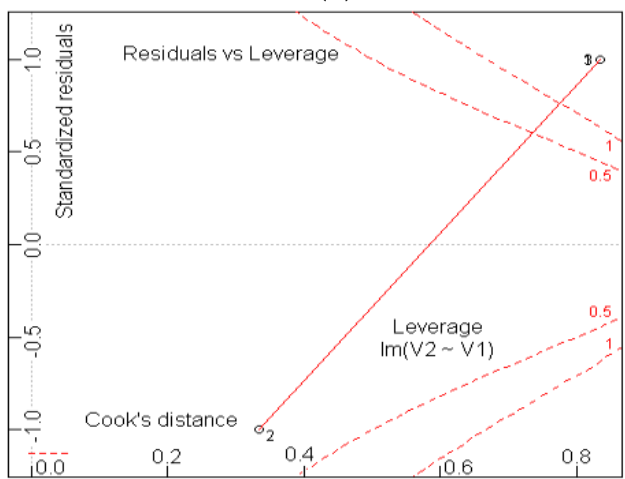

(d)

Fig. 7. Diagnostic charts for model No. 1 (iron oxides - respirable fraction - welding current)

Model No. 2 (second degree curvilinear regression) for iron oxides - respirable fraction is defined by the equation:

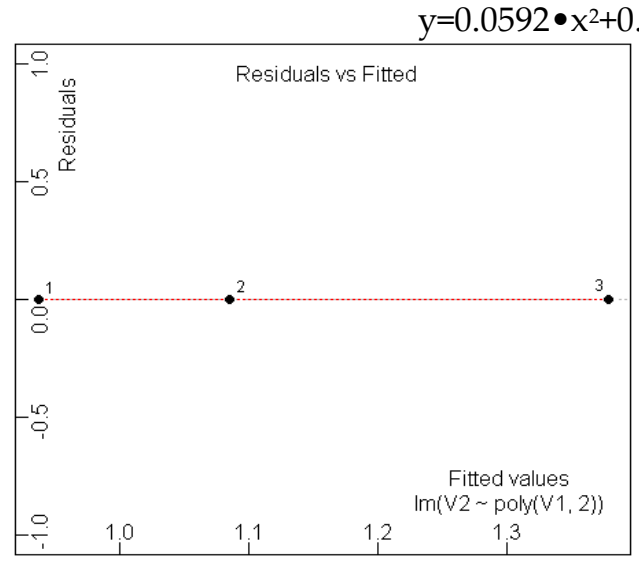

(a)

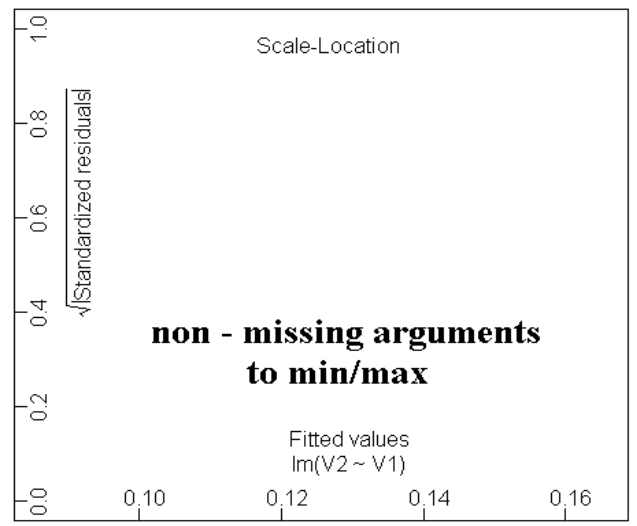

(c)
(4)

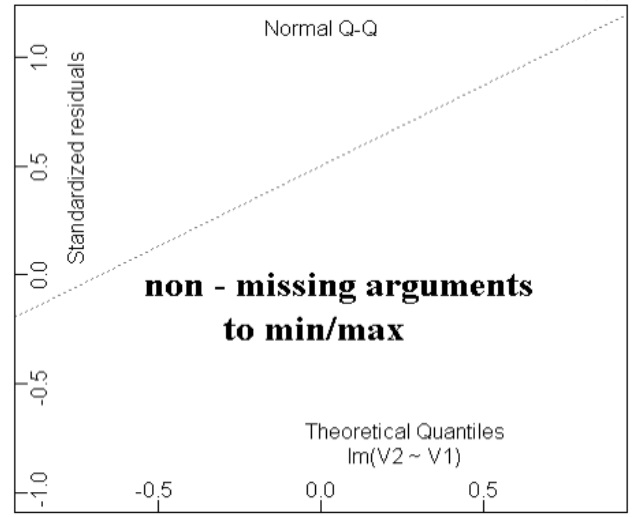

(b)

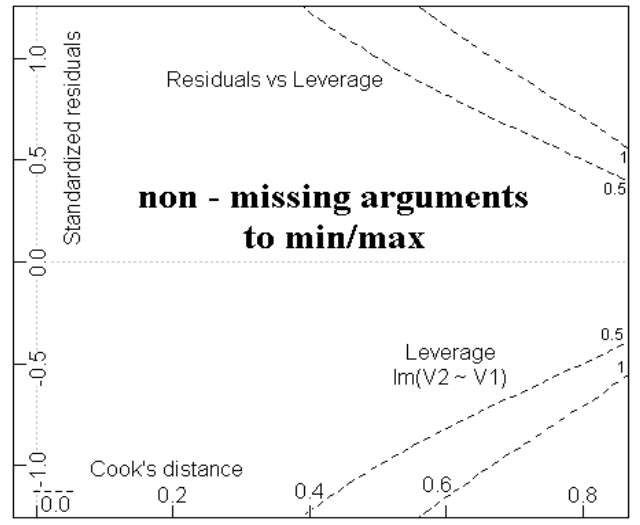

(d)

Fig. 8. Diagnostic charts for model No. 2 (iron oxides - respirable fraction - welding current) 
Table VII. Comparison of the calculated mean value of the emission of iron oxides - the respirable fraction during the welding process with model values

\begin{tabular}{cccc}
\hline Current I [A] & Model No. 1 [mg/m $\left.{ }^{3}\right]$ & Model No. 2 [mg/m $\left.\mathbf{m}^{3}\right]$ & Mean $\left[\mathbf{m g} / \mathbf{m}^{3}\right]$ \\
\hline 110 & 0.913 & 751.751 & 0.937 \\
130 & 1.134 & 1042.147 & 1.085 \\
150 & 1.355 & 1379.903 & 1.378 \\
\hline
\end{tabular}

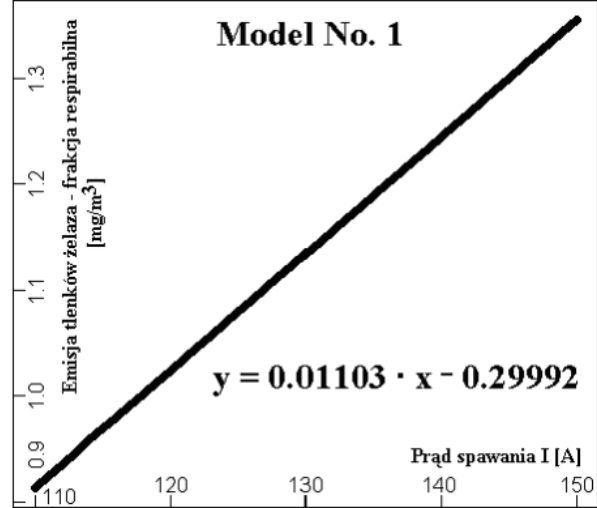

(a)

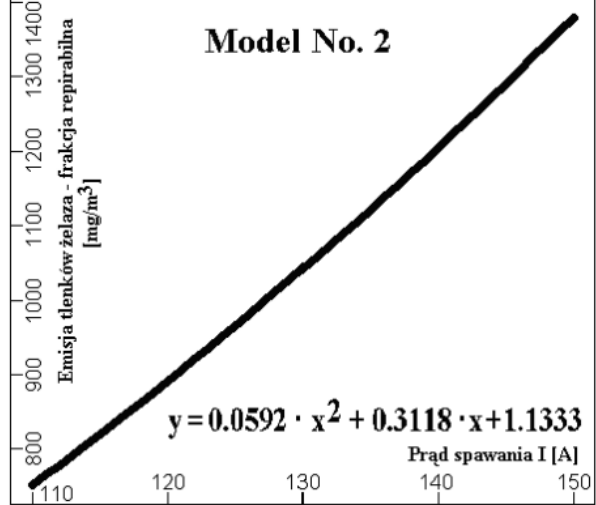

(b)

Fig. 9. Graph of the dependence of the emission of iron oxides - respirable fraction on the welding current based on: a) model No. 1, b) model No. 2

\section{Summary}

After analyzing the obtained test results concerning air pollutant emission during the welding process, the following conclusions can be drawn:

- with increasing welding current, the average value of the emission of iron oxide - inhalable fraction increases from $1.179 \mathrm{mg} / \mathrm{m}^{3}$ (for $\mathrm{I}=110 \mathrm{~A}$ ) to $1.519 \mathrm{mg} / \mathrm{m}^{3}$ (for I=150A);

- for the emission of iron oxides - inhalable fraction no outliers were recorded;

- with increasing welding current, the average value of the emission of iron oxide - respirable fraction increases from $0.937 \mathrm{mg} / \mathrm{m}^{3}$ (for $\mathrm{I}=110 \mathrm{~A}$ ) to $1.378 \mathrm{mg} / \mathrm{m}^{3}$ (for $\mathrm{I}=150 \mathrm{~A}$ );

- for the emission of iron oxides - respirable fraction no outliers were recorded.

From the mathematical models presented here as adequate to the values of the obtained test results, one should assume:

- for iron oxides - inhalable fraction - model No. 1;

- for iron oxides - respirable fraction - model No. 1.

It should be noted, however, that, unfortunately, the above-mentioned models were built for a small data set (only for three welding current values).

Author Contributions: conceptualization, K.P. and J.M.; methodology, K.P.; software, J.M.; validation, K.P. and J.M.; formal analysis, K.P.; investigation, J.M.; data curation, K.P.; writing-original draft preparation, J.M.; writing - review and editing, J.M.; visualization, K.P. and J.M.

Funding: This research received no external funding.

Conflicts of Interest: The authors declare no conflict of interest.

\section{References}

[1] Bendat J. S., Pierdol A. G.: Metody analizy i pomiaru sygnałów losowych. PWN, Warszawa 1976.

[2] Biecek P. Analiza danych z programem R. modele liniowe z efektami stałymi, losowymi i mieszanymi. PWN, Warszawa 2013.

[3] Biecek P. Przewodnik po pakiecie R. Oficyna Wydawnicza GIS, Wroclaw 2017.

[4] Crawley M. The R Book. Wiley-Blackwell 2012.

[5] Czech S.: Spawanie. Wydawnictwo SANNORT Sp. z o.o., Sandomierz 2019.

[6] Dobrowolski Z:: Podręcznik spawalnictwa. Wydawnictwo Naukowo-Techniczne, Warszawa 1978.

[7] Everitt B., Hothorn T.: A Handbook of Statistical Analyses Rusing R. Chapman\&Hall/CRC Comp. Science \& Data Analysis 2010.

[8] Gagolewski M.: Programowanie w języku R. Analiza danych, obliczenia, symulacje. Wyd. Naukowe PWN S.A., Warszawa 2016. 
[9] Gillespie C., Lovelace R.: Wydajne programowanie w R. Praktyczny przewodnik po lepszym programowaniu. APN Promise, Warszawa 2018.

[10] http://www.samochodowkawejherowo.pl/dokumenty/tablice_naprezen (pdf 08.01.2020)

[11] Instrukcja I-03/PO-02. Sprawdzanie aspiratorów. Dokumentacja zakładowa Laboratorium „BIOCHEMIK” Sp. z o.o., Śmiłowo.

[12] Jefferson's Welding Encyklopedia, 18th ed. American Welding Society, 1997.

[13] Koronacki J., Mielniczuk J.: Statystyka dla studentów kierunków technicznych i przyrodniczych. Wyd. WNT, Warszawa 2018.

[14] Krzysztofiak M., Urbanek D.: Metody statystyczne. Państwowe Wydawnictwo Naukowe, Warszawa 1977.

[15] Krzyśko M.: Statystyka matematyczna. Wydawnictwo Naukowe UAM w Poznaniu, Poznań 1996.

[16] Linnert G. E.: Welding Metalurgy. 4-th edition. Vol. I - Fundamentals. Miami, Floryda, AWS 1994.

[17] Luszniewicz A.: Statystyka ogólna. Państwowe Wydawnictwo Ekonomiczne, Warszawa 1987.

[18] Matczak W., Gromiec J. P.: Zasady oceny narażenia spawaczy na dymy i gazy. Wyd. Medycyny Pracy im J. Nofera. Łódź 2003.

[19] Matusiak J., Wyciślik J.: Zdrowie i bezpieczeństwo przy produkcji spawalniczej. Biuletyn Instytutu Spawalnictwa $\mathrm{Nr} 3 / 2009$

[20] Matusiak J., Wyciślik J.: Analiza środowiska pracy przy spawaniu metodą MAG elementów ze stali nierdzewnej i stali niestopowej z cynkową powłoką ochronną. Przegląd Spawalnictwa Nr 87/2011.

[21] Morrison D. F.: Wielowymiarowa analiza statystyczna. Państwowe Wydawnictwo Naukowe, Warszawa 1990.

[22] Mistur L.: Spawanie gazowe i elektryczne. Wyd. Szkolne i Pedagogiczne, Warszawa 1988.

[23] Mistur L.: Spawanie łukowe w osłonach gazowych wg wytycznych krajowych i europejskich (EWF). Wyd. KaBe, Krosno 2004.

[24] Norma PN-Z-04008-7:2002 + Az 1:2004. Ochrona czystości powietrza. Pobieranie próbek. Zasady pobierania próbek w środowisku pracy i interpretacja wyników.

[25] Norma PN-Z-04469:2015-10. Ochrona czystości powietrza. Oznaczanie tlenków żelaza we frakcji respirabilnej aerozolu na stanowiskach pracy metoda płomieniowej adsorpcyjnej spektrometrii atomowej.

[26] Opara S.: Norma ISO 14175 - zmiany dla użytkowników gazów osłonowych. Przegląd Spawalnictwa Nr 5/2010, Warszawa 2010.

[27] Petersen K., Petersena M. :(2008) The matrix cookbook. Technical University of Denmark.

[28] Pinheiro J., Bates D.: (2009) Mixed-Effects Models in S and S-PLUS. Springer.

[29] Praca zbiorowa pod red. Szydłowskiego H.: Teoria pomiarów. Państwowe Wydawnictwo Naukowe, Warszawa 1981.

[30] Robinson G.: (1999) That BLUP is a good thing: the estimation of random effects. Statistical Science, Vol. 6, No. 1, s. $15 \div 32$

[31] Rozporządzenie Ministra Gospodarki z dnia 27 kwietnia 2000r. w sprawie bezpieczeństwa i higieny pracy przy pracach spawalniczych. Dz. U. 2000r., Nr 40, Poz. 470.

[32] Rozp. Ministra Zdrowia z dnia 2 lutego 2011r. w sprawie badań i pomiarów czynników szkodliwych w środowisku pracy.

[33] Seber G.A.F., Lee A.J.: (2003) Linear regression analysis. Wiley, Hoboken, New Jersey.

[34] Sheather S.J.: (2010) A Modern approach to regression with R. Springer, New York.

[35] Tasak E.: Metalurgia spawania. Wydawnictwo JAK, Kraków 2008r.

[36] Wojciechowski W.: Techniki wytwarzania, tom III. Wybrane zagadnienia ze spawalnictwa. Wyd. Politechniki Krakowskiej, 1990.

[37] Voitkevich V.: Welding Fusem. Formation, properties and biological effects. Abington Publishing, Cambrige 1995.

[38] Welding Handbook. Vol. I. Welding Technology. 8-th edition. Miami, Florida, AWS 1991.

[39] Wheeler B.: (2010) Permutation tests for linear models in R. http://cran.r-project.org/web/packages/ lmPerm/vignettes/lmPerm.pdf.

[40] Zeiles A., Hothorn T.: (2010) Diagnostic checking in regression relationships. http://cran.r-project.org/web/ packages/lmtest/vignettes/lmtest-intro.pdf.

[41] Żakowski W., Kołodziej W.: Matematyka cz. II. Analiza matematyczna. Wydawnictwo Naukowo-Techniczne, Warszawa 2003.

(C) 2021 by the authors. Submitted for possible open access publication under the terms and conditions of the Creative Commons Attribution (CC BY) license (http://creativecommons.org/licenses/by/4.0/). 
